\title{
Perkembangan Motif Batik Jepara Tahun 2008-2019: Identitas Baru Jepara Berbasis Kearifan Lokal
}

\author{
Alamsyah, Siti Maziyah, Agustinus Supriyono \\ Departemen Sejarah, Fakultas Ilmu Budaya, Universitas Diponegoro \\ Jl. Prof. Soedarto, S.H. Tembalang, Semarang - Indonesia \\ *Alamat korespondensi:mazy_muiz@yahoo.com \\ DOI: https://doi.org/10.14710/jscl.v5i1.28360
}

Diterima/Received: 2 Februari 2020; Direvisi/Revised: 5 Maret 2020; Disetujui/Accepted: 15 April 2020

\begin{abstract}
Along with the emergence of batik in various places with their respective regional identities, batik also emerged in Jepara with its characteristic motifs. This article aims to determine the development of Jepara batik motifs in 2008-2019 as Jepara's new identity based on local wisdom. The emergence of Batik Jepara has begun in 2008 that became the new identity of Jepara. This identity is further strengthened through the inauguration of batik as a world heritage object by UNESCO in 2009. This study uses literature, observation, and in-depth interview with batik entrepreneurs in Jepara to find out superior motifs and philosophies of each batik motif originating from the local wisdom of the people of Jepara. This identity is what makes Jepara batik motifs different from batik motifs in other places. The results show that the Jepara batik motif was influenced by the local culture of the Jepara community, that is not separated from the Jepara carving motif, Kartini batik motif,Jepara communitylegend, Jepara typical building icons, marine flora-fauna motifs that gave Jepara identity as a coastal area, and the existence of development motifs that remain based on the characteristics of Jepara.
\end{abstract}

Keywords: Motive Development; Jepara Batik; New Identity; Local Knowledge.

Abstrak

Seiring dengan kemunculan batik di berbagai tempat dengan masing-masing identitas kedaerahannya, muncul pula batik di Jepara dengan ciri khas motifnya. Artikel ini bertujuan untuk mengetahui perkembangan motif batik Jepara pada 2008-2019 sebagai identitas baru Jepara yang berbasis kearifan lokal. Kemunculan Batik Jepara dimulai sejak 2008 yang menjadi identitas baru kota Jepara. Identitas ini semakin menguat melalui pengukuhan batik sebagai warisan budaya tidak benda dunia yang telah ditetapkan oleh UNESCO pada 2009. Metode yang digunakan pada penelitian ini adalah metode studi pustaka, observasi, dan wawancara mendalam kepada para pengusaha batik di Jepara untuk mengetahui motif unggulan serta filosofi dari masing-masing motif batik yang berasal dari kearifan lokal masyarakat Jepara. Identitas inilah yang menjadikan motif batik Jepara berbeda dari motif batik di tempat lain. Hasil penelitian menunjukkan bahwa motif batik Jepara dipengaruhi oleh budaya lokal masyarakat Jepara, yaitu tidak lepas dari motif ukir Jepara, motif batik Kartini, legenda masyarakat Jepara, ikon bangunan khas Jepara, motif flora-fauna laut yang memberikan identitas Jepara sebagai daerah pesisir, serta adanya motif pengembangan yang tetap berlandas pada ciri khas Jepara.

Kata Kunci: Perkembangan Motif; Batik Jepara; Identitas Baru; Kearifan Lokal.

\section{Pendahuluan}

Sebelum penghargaan terhadap batik Indonesia oleh UNESCO pada 2009 sebagai warisan budaya tidak benda dunia (http://wartawarga. gunadarma.ac.id/2009/12/tetapkan-batik-seba gai-warisan-budaya-indonesia, dikunjungi pada 7
Mei 2012), semenjak 2006 di berbagai daerah di Jawa diadakan revitalisasi batik. Beberapa daerah yang sebelumnya sudah memiliki sentra pembuatan batik mengalami mati suri, dibangkitkan kembali kepandaian membatiknya dengan penyelenggaraan pelatihan membatik serta lomba membuat desain batik sesuai dengan ikon 
masing-masing daerah. Kegiatan itu mendapat dukungan penuh oleh masing-masing pemerintah daerah serta instansi terkait. Hasil dari pelatihan itu adalah kemunculan Usaha Kecil Menengah (UKM) batik di berbagai daerah dengan kekhasan di masing-masing daerah. Selain menggali motif klasik ciri khas daerahnya, mereka juga mengembangkan motif baru berdasar ikon masingmasing daerah (Maziyah a/b, 2015:1-2). Seiring dengan kemunculan batik di berbagai tempat dengan masing-masing identitas kedaerahannya itu, muncul pula batik di Jepara dengan motif ciri khasnya. Kemunculan batik Jepara pada 2008 ini tidak lepas dari kegairahan untuk menghidupkan kembali kepandaian membatik yang mulai marak sejak 2006 (Triaji, 2018: 90-91).

Penelitian berkaitan dengan usaha kerajinan telah dilakukan oleh beberapa peneliti terdahulu. Kajian yang dilakukan oleh Alamsyah (2012) yang berjudul "Dinamika Sosial Ekonomi Masyarakat Karesidenan Jepara 1830-1900”, memberikan gambaran bahwa pada akhir abad ke19 batik Jepara telah berkembang di seluruh wilayah Jepara. Dengan demikian, dapat dikatakan bahwa kerajinan batik Jepara mempunyai akar sejarah dan eksistensi yang cukup lama. Hal ini menandakan bahwa masyarakat Jepara mempunyai berbagai kegiatan ekonomi kreatif dalam kehidupan rakyatnya. Topik serupa juga dikaji oleh Alamsyah (2013) yang berjudul "Kreativitas Ekonomi Masyarakat Lokal di Karesidenan Jepara 1830-1900”, yang mengisahkan kelahiran industri kreatif berbasis pada skill atau keahlian dengan memanfaatkan sumber daya alam yang tersedia.

Kajian selanjutnya dilakukan oleh Indrahti dan Laksono (2014 dan 2015), berjudul "Pemetaan Klaster Kerajinan sebagai Model Pengembangan Wisata Kerajinan di Jepara”. Hasil kajian ini menunjukkan bahwa di Jepara terdapat berbagai klaster kerajinan termasuk klaster kerajinan batik sebagai klaster kerajinan termuda. Beberapa motif batik Jepara yang dibuat oleh para pengrajin terinspirasi dari batik karya Kartini dan motif ukir Jepara.

Alamsyah (2014) juga melakukan kajian mengenai dinamika industri kerajinan Tenun Troso di Jepara. Kajian ini mengisahkan tenun Troso sebagai bentuk kerajinan yang lebih dekat ke arah usaha kecil yang membuat ekonomi masyarakat semakin dinamis karena sebagian besar masyarakat terlibat dalam proses produksinya. Pada perkembanganya, seiring dengan kemunculan batik di Jepara, muncul inovasi tenun Troso yang dibatik dengan motif khas Jepara.

Maziyah $(2015 b)^{1}$ dalam kajiannya yang berjudul Ornamen Mantingan menyatakan bahwa ragam hias pada Masjid dan Makam Mantingan di Jepara sebagai salah satu inspirasi motif kerajinan batik Jepara yang berasal dari motif yang terdapat pada medalion yang ditempelkan di dinding Masjid Mantingan.

Berdasar pada kajian-kajian yang telah ada, perkembangan motif batik di Jepara belum disinggung secara spesifik. Pada penelitian terdahulu itu, batik Jepara hanya disinggung sebagai bagian dari kerajinan yang terdapat di Jepara. Oleh karena itu, pada artikel ini diidentifikasi mengenai kekhasan motif batik di Jepara pada 2008 hingga 2019, yang dapat membedakan dari motif batik di daerah lain, sehingga bisa menjadi identitas baru bagi Jepara.

\section{Metode}

Identifikasi motif batik Jepara dimulai dengan studi pustaka sebagai studi komparasi dalam menjelaskan fenomena-fenomena yang sama atau memiliki kemiripan dengan objek kajian, tetapi berbeda lokasi atau pun periodisasi waktunya (Sjamsudin, 2007: 85-89). Dalam rangka menggali informasi berkaitan dengan motif batik, maka dilakukan observasi langsung dengan cara mengunjungi dan melihat langsung objek yang diteliti (Basuki, 2006: 150) yaitu komunitas batik di Jepara. Observasi ini bertujuan untuk memperoleh deskripsi yang lebih utuh tentang motif batik, dan landasan filosofisnya, serta kondisi yang melatarbelakangi kemunculan motif itu (Koentjaraningrat, 1997: 114-115).

Sementara itu, wawancara mendalam (Basuki, 2006: 171-173) kepada para pengusaha batik di Jepara dilakukan untuk mengetahui motif unggulan serta filosofi dari masing-masing motif batik yang berasal dari kearifan lokal masyarakat Jepara. Identitas ini yang menjadikan motif batik Jepara berbeda dari motif batik di tempat lain. 
Penelitian ini juga menggunakan pendekatan antropologis yang memfokuskan pada studi etnohistoris yaitu berbagai aktivitas masyarakat, budaya, sejarah, dan nilai-nilai tradisi lokal yang di masa sekarang masih berkait atau mencerminkan pengetahuan dan kehidupannya di masa lampau yang mempunyai kaitan dengan batik dan makna budaya.

Semua data yang telah dikumpulkan baik melalui sumber primer (dokumen, produk batik, wawancara), sumber sekunder (studi sebelumnya yang relevan dan pustaka), serta pendekatan yang digunakan, selanjut-nya diklasifikasikan dan diakumulasikan antara data satu dengan lainnya sebagai suatu bentuk interpretasi dan disintesiskan dalam rangka mewujudkan historiografi tentang motif batik Jepara.

\section{Jepara: Kota Pelabuhan Tua}

Jepara merupakan salah satu kota tua yang terdapat di Pantai Utara Jawa. Kota ini memiliki sejarah panjang (Graaf dan Pigeaud, 2003:117) yang berkaitan dengan posisi geografisnya yang berada di daerah pesisir. Qingxin (2006:47) menyebutkan bahwa Jepara merupakan salah satu kota pelabuhan dan pusat perdagangan laut internasional di Asia Tenggara semenjak abad ke-7 hingga abad ke-9 $\mathrm{M}$. Tidak mengherankan jika pada waktu itu di Holing $^{3}$ telah berdatangan pedagang dari berbagai bangsa seperti dari India, Cina, Persia, dan Arab (Gungwu, 2007:115; Groeneveldt, 2009:20-21; Maziyah, 2017a:7).

Selain Pegu, Ayutthaya, Pnompenh, Hoi An (Faifo), Melaka, Patani, Brunei, Pasai, Aceh, Banten, Gresik, dan Makassar, menurut Reid (2011b:3) Jepara merupakan salah satu pusat perdagangan di "wilayah bawah angin". Peran Jepara sebagai titik temu perdagangan laut internasional itu terus berlangsung hingga abad ke16 M (Graaf dan Pigeaud, 2003:13; Hayati, dkk, 2007: 53-67). Kehancuran Jepara disebabkan oleh serangan Kerajaan Mataram Islam pada 1599 (Graaf dan Pigeaud, 2003: 122). Setelah itu Jepara menjadi bagian dari Kerajaan Mataram Islam dan secara berangsur-angsur kota itu kehilangan perannya sebagai kota pelabuhan internasional akibat penguasaan Malaka oleh Portugis semenjak 1511 (Reid, 2011a: 3) dan pendangkalan laut
Jepara akibat sedimentasi pada awal abad ke-17 (Nagtegaal, 1996).

Menurut cerita rakyat, seperti yang terdapat pada Literature Jilid III, Pigeaud (Graaf dan Pigeaud, 2003: 300-301) menunjukkan legenda yang mengisahkan bahwa dahulu kota tua ini merupakan tempat tinggal Sandang Garba, raja para pedagang dalam alam mitos, putra kedua dari Suwela Cala sebagai penguasa di Medang Kamulan. Sandang Garba memiliki hubungan dagang dengan raja-raja di seberang laut dan dengan orang Spanyol. Menilik sudah disebutkannya Spanyol di dalam legenda itu, menunjukkan bahwa kemungkinan waktu yang dibicarakan oleh legenda itu adalah abad ke-16, yaitu waktu awal kedatangan orang Spanyol ke Tanah Jawa. Secara tersirat, legenda itu juga menunjukkan bahwa pada abad ke-16 Jepara masih eksis sebagai kota pelabuhan perdagangan laut internasional (Hayati, dkk., 2007:53-67).

Nama Sandang Garba, menunjukkan adanya perhatian yang berlebih berkaitan dengan sandang atau pakaian. Menurut Frederici (1581:268), gaya pakaian masyarakat Asia Tenggara itu sama antara orang bangsawan dan orang biasa, yang membedakannya adalah kehalusan kainnya. Hal ini sesuai dengan hasil penelitian Maziyah (2017a; 2017b; 2018a) yang menunjukkan bahwa pada abad ke-9 hingga abad ke-14 telah terdapat berbagai kain halus buatan bangsawan Jawa dan kain impor hasil perdagangan internasional. Kain-kain itu banyak diminati oleh para bangsawan Jawa Kuna. Bangsawan Jepara sebagai pemilik kota pelabuhan ini tentu mudah untuk berhubungan dengan para pedagang pemasok kain seperti India, Cina, dan Arab, serta mudah untuk mendapatkan kain sesuai dengan yang diinginkannya.

Meskipun demikian, informasi yang berkaitan dengan kain yang dibuat atau terdapat di Jepara pada abad ke-7-16 sulit ditemukan. Informasi berkaitan dengan kain, khususnya kain batik, baru banyak ditemukan pada masa Kartini.

\section{Motif Batik Jepara Sebelum 2008}

Informasi paling awal berkaitan dengan keberadaan kain batik di Jepara menurut Suyanti Djatmiko adalah kain yang disebut dengan kalyaga, 
yaitu salah satu jenis kain yang terkenal di Jepara pada masa Ratu Kalinyamat. Menurut cerita tutur, kain kalyaga bermotif persemaian (semen) itu dibuat oleh Ratu Kalinyamat untuk dihadiahkan kepada Joko Tingkir (wawancara dengan Ibu Suyanti Djatmiko pada 5 Januari 2016). Sebetulnya kalyaga adalah istilah yang berasal dari bahasa Jawa Kuna, yang menunjukkan pada jenis kain tenun yang berwarna merah dari bahan celup kulit kayu pohon kalyāga (Zoetmulder, 2000:447). Kain kalyaga ini pada abad ke-9 hingga abad ke-15 merupakan salah satu jenis kain halus untuk dipersembahkan kepada para bangsawan Jawa, seperti informasi yang terdapat pada Prasasti Lintakan 919 M yang menyatakan bahwa kain itu dipersembahkan kepada tiga pejabat Kerajaan Mataram Hindu, yaitu Rakai Halu Pu Siṇ̣ok, Rakai Sirikan Pu Haway, dan Rakai Wka Pu Kiraña (Wurjantoro, 2012:221). Kemungkinan jenis kain ini terus diproduksi oleh bangsawan Jawa, termasuk oleh Ratu Kalinyamat sebagai bangsawan Jawa pada abad ke-16.

Pada 1559, Ratu Kalinyamat membangun Masjid dan Makam Mantingan (Leeuwendal, 1931:52). Pada dinding masjid itu dihiasi medalion-medalion yang berasal dari batu putih berukiran berbagai tumbuhan menjalar yang menggambarkan pemandangan, serta berbagai bunga, motif kelelawar, serta motif geometris, yang menurut cerita tutur Jepara dibuat oleh Tji Whui Gwan atau lebih dikenal dengan nama Sungging Badar Duwung (Maziyah, 2015b: 39). Adrisianti dan Abdullah (2015: ii) menyatakan bahwa medalion motif lotus seperti Gambar 1 merupakan ukiran motif lotus gaya yui, salah satu motif Cina pada abad ke-16, yang terdapat di Masjid Mantingan.

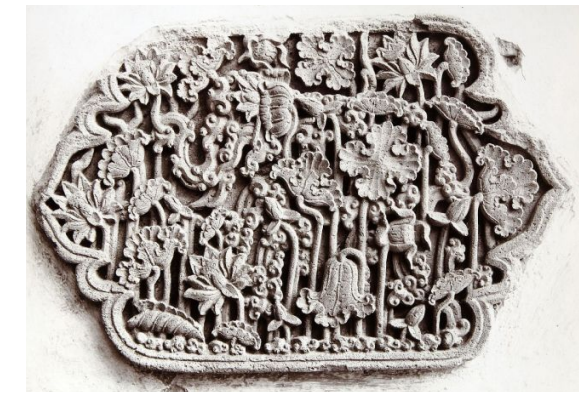

Gambar 1. Ukiran Motif Lotus Gaya Yui di Masjid Mantingan.

Sumber. Dokumentasi Penulis, 2018.
Jepara menjadi daerah bawahan Kerajaan Mataram Islam pada awal abad ke-17 (Graaf dan Pigeaud, 2003:122), selanjutnya dipimpin oleh Kyai Demang Laksana (Kohar, 2013:50). Pada masa itu, pengaruh kesenian dan kebudayaan Kerajaan Mataram Islam masuk di Jepara termasuk gaya hidup para bangsawan yang mengenakan kain batik gaya Mataraman. Tidak tertutup kemungkinan bahwa yang menyebarluaskan batik di Jepara ini adalah para penguasa Jepara yang berasal dari Kerajaan Mataram Islam, sehingga tidak mengherankan jika motif batik Jepara berwarna soga, khas warna batik gaya Mataraman, seperti karya-karya batik yang dibuat R.A. Kartini pada awal abad ke-20. Selain itu, batik karya Kartini juga mendapat pengaruh kesenian Belanda dengan menggambarkan buketan ${ }^{5}$ bunga anyelir, tanpa meninggalkan budaya Jawa yang terlihat pada latarnya yang berbentuk galaran ${ }^{6}$ seperti pada Gambar 2.

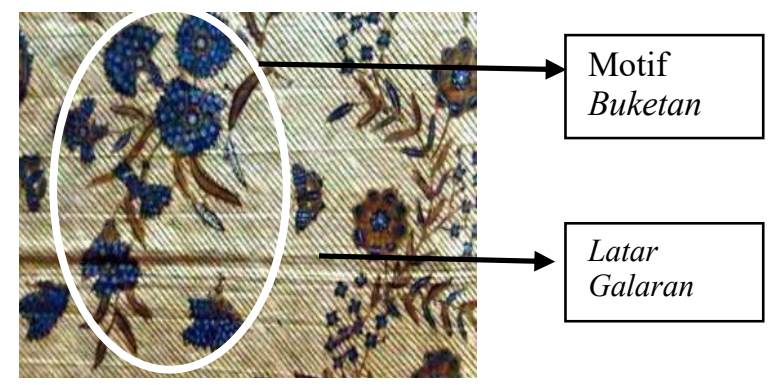

Gambar 2. Contoh Batik Karya Kartini

Sumber: https://gaya.tempo. co/silsilah-batik-kartini dikunjungi pada 10 September 2014

Sejarah batik di Jepara terkait dengan peran R.A. Kartini yang telah mengenalkan batik Jepara ke dunia internasional pada Pameran Nasional untuk Karya Wanita di Den Haag pada 1898. Selain memamerkan batik Jepara, Kartini melengkapinya dengan naskah berbahasa Belanda halus yang berkaitan dengan cara membuat batik, berdasar pada pengalamannya membatik dan penelitiannya terhadap para pembatik Kabupaten Jepara. Naskah itu mengilhami karya Rouffaer dan Juynboll tentang seni membatik di Jawa (Toer, 2000: 158-159).

Meskipun demikian, Jepara bukan merupakan pusat produksi batik di Jawa (Susanto, 1973:315). Oleh karena itu, tidak mengherankan jika tidak semua orang mengenal motif batik Jepara. Di Jepara, membatik hanya merupakan 
kesenangan semata. Kain batik hanya digunakan untuk diri sendiri dan keluarganya bukan untuk diperjual-belikan. Seperti yang dilakukan oleh R.A. Suci, salah satu murid R.A. Kartini, yang membuatkan semua putra-putrinya kain batik. Beberapa motif batik yang dibuat olehnya adalah Parang Gondosuli Buketan, Parang KanthiP, Lung ${ }^{10}$ Kanthil, dan Kopi Pecah (Alamsyah, dkk., 2018: 22-25). Jika diperhatikan, motif batik yang dibuat oleh R.A. Suci itu terpengaruh oleh R.A. Kartini yang menuangkan berbagai motif dengan latar belakang budaya yang berbeda, yaitu gaya Mataraman (parang dan gondosuli), Jepara (kanthil, lung, dan kopi pecah) dan Belanda (buketan). Gambar 3 merupakan salah satu motif batik karya R.A. Suci.

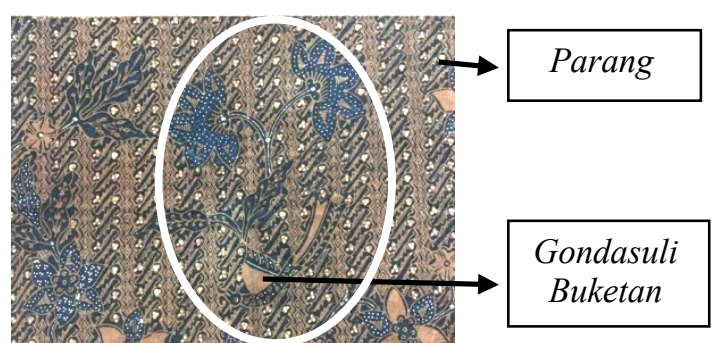

Gambar 3. Motif Parang Gondosuli Buketan

Sumber: Alamsyah, dkk., 2019:22.

Batik Jepara juga dapat diketahui dari hasil karya R.A. Kardinah, salah satu adik R.A. Kartini yang menikah dengan Bupati Tegal (1908-1936) yang bernama Raden Mas Ario Reksonegoro. Di Tegal, Kardinah mendirikan sekolah kepandaian putri dan mengajarkan kepandaian membatik kepada murid-muridnya (Fatkhudin, 2010:57). Kardinah yang berasal dari Jepara membawa serta kebudayaannya melalui motif batik Jepara maupun motif Lasem. Pengaruh motif Lasem itu menggunakan warna merah, kuning, coklat, biru dan hijau, sehingga di Tegal motif ini disebut motif bangjo. Meskipun demikian, Kardinah memiliki kesukaan yang sama dengan Kartini dalam memberi warna batik yaitu coklat dan hitam (Maziyah, 2018b:180;187). Gambar 4 dan 5 merupakan contoh batik karya Kardinah.

Berdasar pada motif-motif yang dihasilkan di atas, dapat diketahui bahwa motif batik Jepara merupakan perpaduan dari berbagai budaya yang melingkupi pembuatnya, yaitu motif klasik gaya Mataraman, motif Jepara, motif Lasem, serta motif Belanda. Hal ini sesuai dengan yang dikatakan oleh
Doellah (2000:154), bahwa sehelai kain batik dapat menunjukkan latar belakang dan lingkungan budaya pembuatannya.

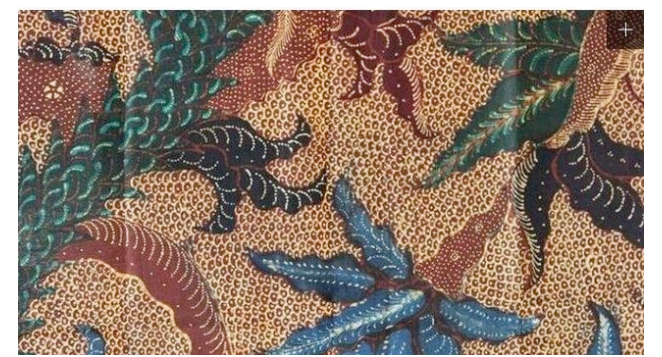

Gambar 4. Batik Bangjo Motif Tumbar Bolong

Sumber: http://regional.liputan6.com/read

/3116234/kisah-keluarga-ra-kartini-angkat-derajatbangsa-melalui-batik, diakses pada 30 November 2017.

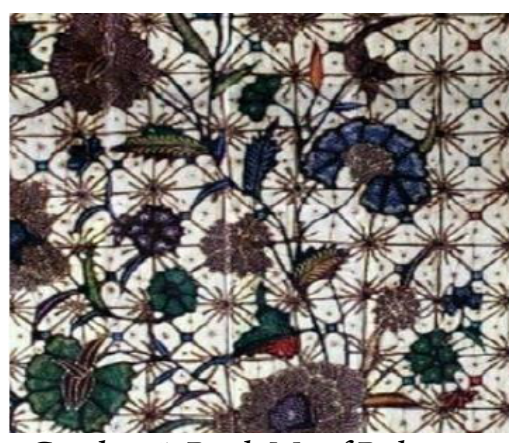

Gambar 5. Batik Motif Buketan

Sumber:http://regional.liputan6.com/read/3116234/

kisah-keluarga-ra-kartini-angkat-derajat-bangsamelalui-batik, diakses pada 30 November 2017.

Sepeninggal R.A. Suci dan R.A. Kardinah, batik Jepara mengalami kemunduran secara tajam hingga dapat dikatakan mati suri. Hal ini antara lain dipicu oleh Perang Dunia II yang membawa perubahan besar pada berbagai kehidupan di seluruh dunia, termasuk bagi dunia batik, karena pasokan kain mori dan zat pewarna sintetis menjadi terganggu. Keadaan ini menjadi lebih parah ketika Jepang menduduki Indonesia, mori halus sebagai bahan utama batik sulit diperoleh (Doellah, 2000: 202). Inilah yang menyebabkan batik Jepara menjadi mati suri pada pertengahan hingga akhir abad ke-20.

\section{Motif Batik Jepara pada 2008-2019}

Batik Jepara dapat ditelisik keberadaannya kembali berkat penelitian yang dilakukan oleh Indrahti dan Laksono (2014) yang berkaitan dengan klaster kerajinan di Jepara. Kerajinan yang dibidik pada 
penelitian ini meliputi kerajinan rotan, monel, tenun ikat Troso, kerajinan patung dan souvenir, kerajinan meubel in-door dan out door, serta batik (Alamsyah, 2015). Di antara kerajinan itu, keberadaan kerajinan batik kemunculannya paling akhir, yaitu 2008 (Wawancara dengan M. Latif Jauhari pada 18 September 2014).

Kemunculan kembali batik Jepara tidak lepas dari peran Suyanti Djatmiko, cucu mantu R.A. Suci, salah satu murid Kartini yang pandai membatik. Suyanti memiliki latar belakang keluarga pengusaha ukir Jepara. Meskipun demikian, karena ia sangat menyukai seni dan melihat bahwa seni membatik di Jepara sudah mati suri, maka pada 2004 hingga 2005 ia berusaha untuk menelisik motif batik Jepara melalui bukubuku yang berkaitan dengan Kartini maupun pencariannya di beberapa museum. Sejak 2006, ia mulai memproduksi batik dengan motif ukir. Pada 2008 menjadi tonggak kemunculan kembali batik Jepara dengan pencanangan Deklarasi Batik Jepara di Pendopo Kabupaten Jepara. Semenjak itu, mulailah batik Jepara atau batik Kartini ini menggeliat di Jepara (Wawancara dengan Suyanti Djatmiko, 27 Mei 2014 dan 10 September 2014). Berdasar wawancara dengan para pengrajin batik di Jepara, motif batik yang diminati para pembatik Jepara pada kurun waktu 2008-2019 adalah motif ukir Jepara, motif yang berkaitan dengan batik Kartini, motif yang berkaitan dengan legenda, serta memodifikasi motif yang terdapat pada medalion Masjid Mantingan, flora dan fauna ciri khas Jepara, serta motif pengembangan.

\section{Batik Motif Ukir Jepara}

Berdasar pada wawancara dengan para pembatik Jepara, terungkap bahwa sebagian besar para pengrajin batik Jepara itu memiliki latar belakang dari keluarga pengukir, sehingga mereka masih merekam berbagai motif ukiran. Bahkan, Dewi Irawati masih menyimpan berbagai contoh motif ukiran milik ayahnya (Wawancara Dewi Irawati, 22 Juni 2019. Oleh karena itu, tidak mengherankan jika semua pengrajin itu selalu membuat motif ukir Jepara di dalam motif batiknya. Menurut Suyanti Djatmiko, ciri khas motif ukir Jepara itu terdiri atas tiga bagian, yaitu (1) Daun Jumbrang, istilah lokal Jepara untuk menyebut daun ubi jalar (Ipomoea batatas); (2). Lung-lungan, merupakan penggambaran batang ubi yang menjalar; dan (3). Buah Wuni (Antidesma bunius) (Wawancara dengan S. Djatmiko, 22 Juni 2019). Gambar 6 merupakan gambar dasar motif ukir Jepara itu. Beberapa motif batik yang terinspirasi motif ukir Jepara adalah seperti contoh pada Gambar 7.

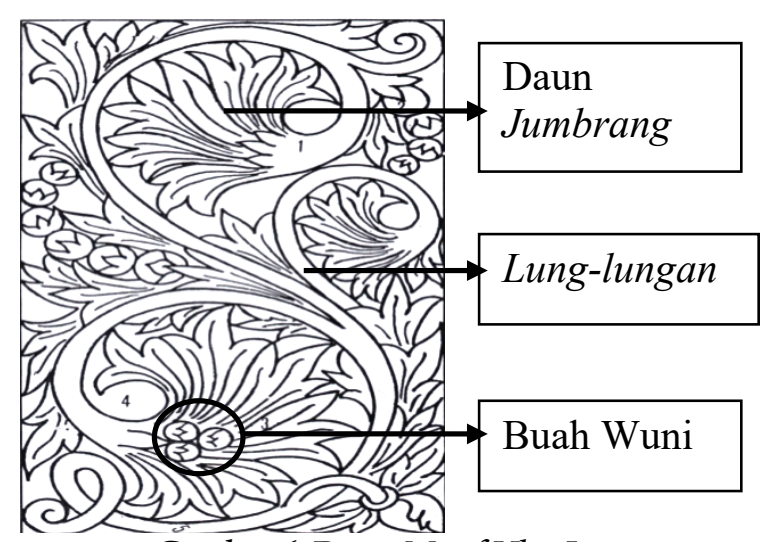

Gambar 6. Dasar Motif Ukir Jepara Sumber: Kadir, 1979: 21

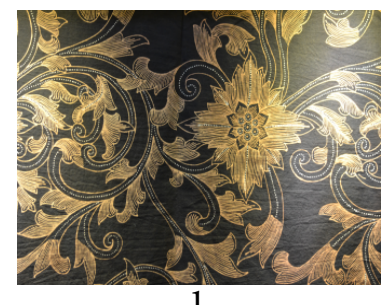

1
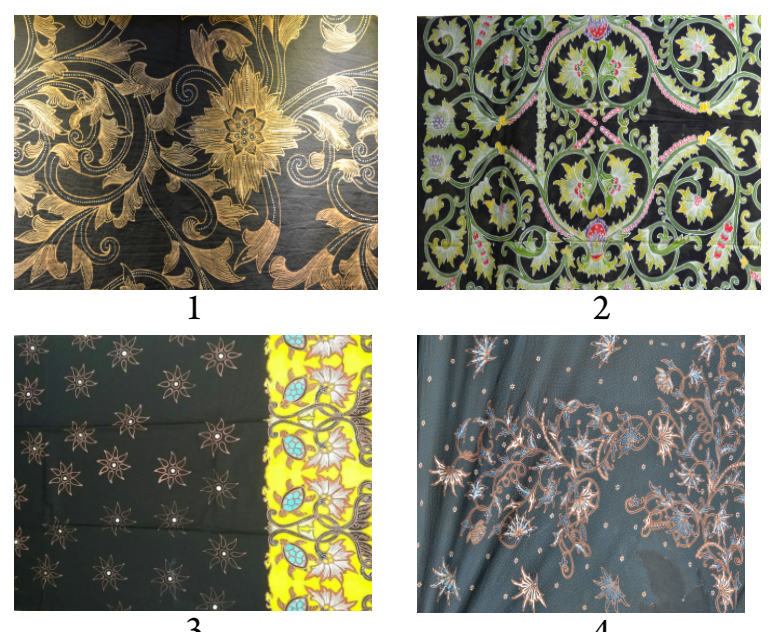

4

Gambar 7. Batik Motif Ukir Jepara Karya Suyanti Djatmiko (1), Dewi Irawati (2), Nunung Windiani (3), dan Sukim (4).

Sumber: Alamsyah, dkk., 2019: 35, 61, 113, 123.
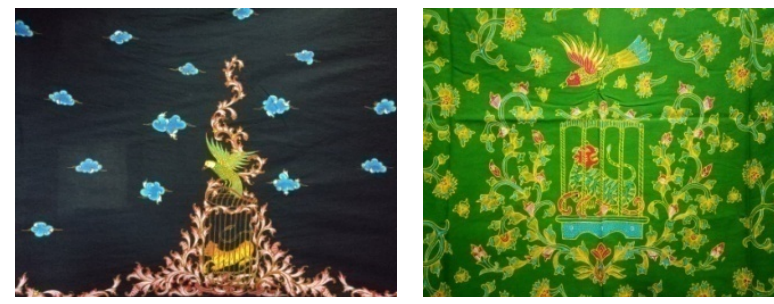

Gambar 8. Kreasi Batik Nurunnikmah Awwalina Sumber: Alamsyah, dkk., 2019: 132-133.

Nurunnikmah Awwalina memiliki ciri khas yang berbeda dari para pengrajin batik yang lain. Motif ukir Jepara yang dituangkan pada batik 
ciptaannya, selalu mengangkat motif macan kurung, salah satu ikon ukir Jepara. Gambar 8 merupakan contohnya.

\section{Batik Motif Kartini}

Menurut Suyanti Djatmiko, Erlisa Sulasmi, dan Dewi Irawati (wawancara pada 27 Mei 2014), yang dimaksud dengan batik motif Kartini adalah motif batik yang dibuat oleh Kartini pada zamannya. Motif-motifnya terinspirasi dari tanaman yang berada di sekeliling Pendopo Kabupaten Jepara, seperti bunga melati, bunga kanthil, dan daun semanggi, serta budaya yang dikenal Kartini pada zamannya, yaitu budaya Mataraman dan budaya Belanda. Beberapa contoh motif batik yang terinspirasi oleh batik Kartini adalah seperti Gambar 9.
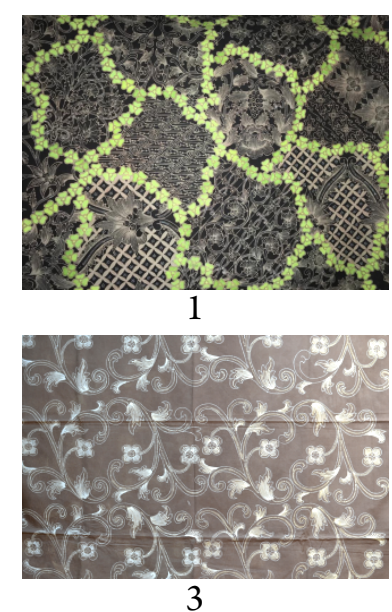

Gambar 9. Batik Kartini Karya Suyanti Djatmiko (1), Alfiyah (2), Dewi Irawati (3), dan Erlisa Sulasmi (4).

Sumber: Alamsyah, dkk, 2019: 30, 83, 62.

Motif Sekarjagad Semanggi (1) dibuat oleh Suyanti Djatmiko yang terinspirasi dengan Kartini yang selalu bertiga dengan Kardinah dan Rukmini, sehingga mereka dahulu sering disebut dengan daun semanggi (Marsilea drummondii L.). Alfiyah membuat motif Merak Kanthil Jepara (2) karena terinspirasi dengan binatang piaraan Kartini serta bunga kanthil (Magnolia $x$ alba) yang terdapat di sekitar Pendopo Kabupaten Jepara, demikian juga dengan Erlisa Sulasmi (4). Adapun Dewi Irawati membuat motif sekar melati (3) sebagai salah satu bunga kesayangan Kartini yang berbau harum. Melihat kreasi para pengrajin batik terhadap batik Kartini, menunjukkan bahwa mereka memahami kiprah Kartini terutama di bidang seni membatik.

\section{Motif Batik Terkait Masjid Mantingan}

Masjid Mantingan secara singkat sudah disinggung pada bahasan di atas. Masjid yang memiliki medalion dengan motif hiasnya yang khas mampu menumbuhkan kreativitas masyarakat di sekitarnya untuk menuangkannya pada karya seni. Berdasar pada penelitian Maziyah, dkk. (2015:73, 118), Masjid Mantingan menumbuhkan ekonomi kreatif masyarakat di Jepara di bidang ukir dan batik. Gambar 10 merupakan contoh motif batik yang terinspirasi oleh hiasan yang terdapat pada Masjid Mantingan yang dibuat oleh Dewi Irawati.

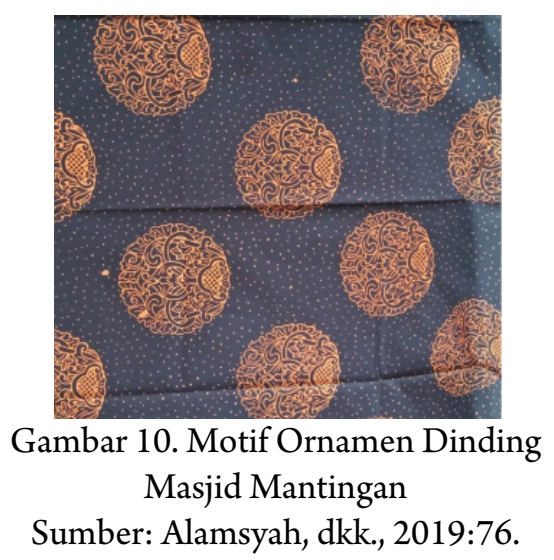

Ornamen yang terdapat pada Masjid Mantingan tidak hanya satu macam, tetapi ada berbagai macam. Semuanya motifnya menarik dan luwes jika dituangkan dalam motif batik. Dewi Irawati membuat beberapa motif yang terinspirasi dari Masjid Mantingan, demikian pula yang dilakukan oleh Erlisa Sulasmi.

\section{Motif Batik Terkait Legenda dan Upacara Tradisi}

Salah satu ikon Jepara yang melegenda adalah kurakura. Belum diketahui secara pasti hubungan antara kura-kura (Testudines) dan Jepara, sehingga di Pantai Kartini dibangun aquarium yang berbentuk kura-kura. Di antara 10 pengrajin batik yang membuat motif kura-kura adalah Erlisa Sulasmi, Dewi Irawati, dan Titik Susanti. Sementara itu, Nurunnikmah Awwalina, mengangkat upacara tradisi Jepara pesta lomban dan perang obor ${ }^{11}$ dalam motif batik. Jepara merupakan salah satu daerah yang memiliki dua kebudayaan, yaitu kebudayaan maritim dan kebudayaan agraris. Pesta lomban mewakili kebudayaan maritim diwakili dengan adanya motif perahu, sedangkan perang obor mewakili 
kebudayaan agraris yang dilatarbelakangi oleh adanya pageblug atau wabah penyakit di daerah Tegalsambi (Indrahti, dkk., 2016), diwakili oleh motif orang-orang yang saling berhadapan dengan masing-masing memegang obor. Gambar 11 merupakan motif-motif batik itu.

\section{Motif Batik Terkait Flora dan Fauna Jepara}

Flora atau tumbuh-tumbuhan khas Jepara telah mengilhami para pengrajin untuk membuatnya menjadi motif batik. Hampir semua tumbuhtumbuhan sederhana itu memiliki keterkaitan sejarah, khususnya sejarah Kartini dan sejarah ukir Jepara. Daun dan batang ubi jalar, buah wuni, bunga melati, bunga kanthil, bunga mawar, daun semanggi, daun simbar menjangan (Platycerium), dan berbagai tanaman sederhana yang lain telah mengilhami para pembatik untuk menuangkannya dalam motif batik. Beberapa contoh gambar di atas telah menunjukkan hal itu.

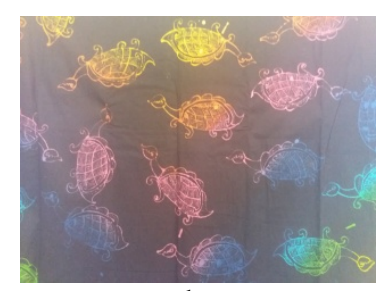

1

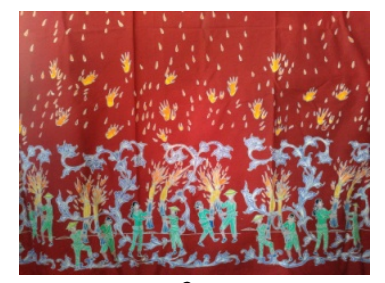

3

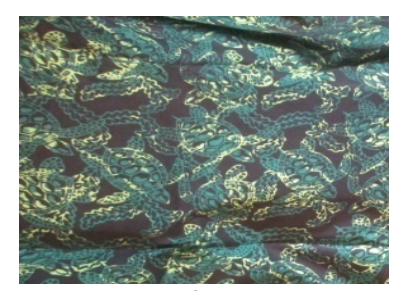

2

4

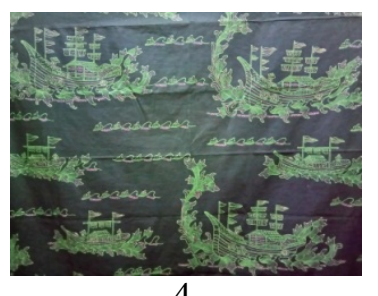

Gambar 11. Motif Batik Terkait Legenda dan Upacara Tradisi: Kura-Kura (1,2); Perang Obor (3), dan Pesta Lomban (4).

Sumber: Alamsyah, dkk., 2019: 136, 140, 155.
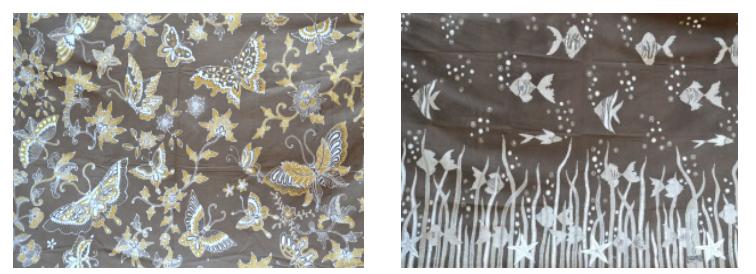

Gambar 12. Motif Batik Fauna

Sumber: Alamsyah, dkk., 2019:88-89.

Sementara itu, fauna atau hewan khas Jepara turut serta menjadi inspirasi para pengrajin batik untuk menjadikannya motif batik. Ada merak, berbagai serangga, dan berbagai binatang laut yang digunakan sebagai motif batik Jepara. Gambar 12 merupakan contoh gambar batik motif fauna karya April Puji Astuti.

\section{Motif Batik Pengembangan}

Motif batik pengembangan adalah motif batik baru yang dikembangkan berdasar pada potensi lokal suatu daerah. Biasanya motif batik pengembangan ini berbeda dari motif yang sudah ada sebelumnya. Di Jepara, ada dua pengrajin batik yang memiliki keistimewaan dalam motif batiknya, yaitu April Puji Astuti dan Titik Susanti. Motif batik karya April Puji Astuti mencerminkan Jepara sebagai daerah maritim. Berikut ini adalah nama motif batik karyanya: Pesona Karimunjawa, Oceanografi, Asmaradana Lung Jepara, Miyang ${ }^{12}$, Lelangan ${ }^{13}$, Trus Karya Tataning Bumi ${ }^{14}$, Kepis ${ }^{15}$ Segaran, The Beauty of Java Tentik $k^{16}$, Pesona Pulau Panjang, Kupu Tarung, dan Kapal Pecah. Gambar 13 merupakan contoh motif batik karya April Puji Astuti.

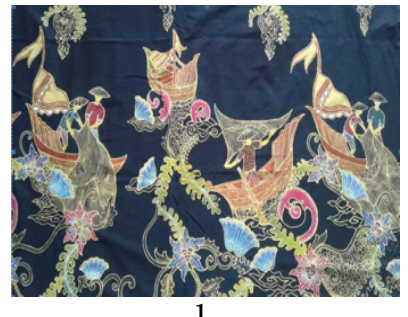

1

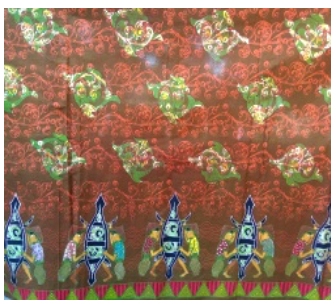

2
Gambar 13. Motif Pesona Karimunjawa (1) dan Miyang (2)

Sumber: Alamsyah, dkk., 2019: 170, 173.

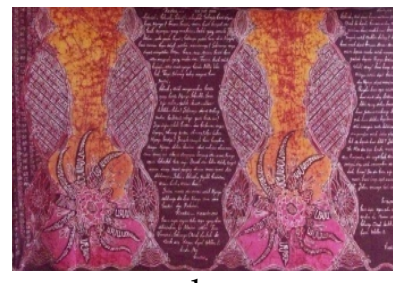

1

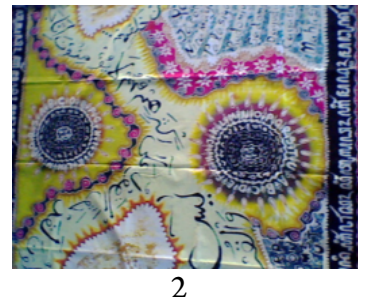

Gambar 14. Motif Batik Surat Kartini (1) dan Mix Aksara (2)

Sumber: Alamsyah, dkk., 2019: 146,149.

Adapun ciri khas motif batik Titik Susanti berupa aksara, baik aksara Jawa, Latin, maupun Arab. Meskipun demikian, ciri kejawaan atau Jeparanya sangat kental, karena selalu dikaitkan dengan Kartini atau kebudayaan Jawa. Beberapa contoh motif batik yang telah dibuat adalah Surat Kartini, Tapak Jawa, Aksara Mantra Pengasih, Mix 
Aksara, Burung Aksara, Naga Jawa Kepala Tiga, Nusantara I, Nusantara II, Pesona Serangga, KuraKura Jepara, dan Terumbu Karang Bandengan. Gambar 14 merupakan contoh motifnya.

\section{Simpulan}

Secara historis, seni batik tradisional di Jawa sudah ada sejak zaman Majapahit, bahkan jauh sebelum itu. Keberadaan batik sebagai karya seni bangsa Jawa semakin berkembang pada akhir abad ke-18 atau awal abad ke-19 masa Hindia Belanda. Saat ini, perkembangan batik semakin intensif karena di seluruh daerah di Jawa Tengah mempunyai identitas batik dengan motif khas lokal.

Jepara sebagai daerah pesisir dan kota ukir juga mengembangkan motif batik sebagai identitas lokal. Perkembangan ini tidak dapat dilepaskan dari peran R.A. Kartini sebagai salah satu tokoh yang menggerakkan kerajinan batik dari hulu sampai hilir, mulai dari membuat batik, pelatihan, pemasaran dilakukan, sehingga batik Jepara pada akhir abad ke-19 juga mengisi pameran di negeri Belanda. Motif batik yang dikembangkan Kartini masih mengikuti motif klasik Mataraman yang diadaptasi dengan motif lokal serta motif Belanda. Namun demikian, pada saat ini motif batik Jepara lebih beragam disesuaikan dengan potensi lokal. Motif ukir mendominasi batik Jepara, hal ini menunjukkan bahwa para pembatik Jepara sangat dekat dengan kesenian ukir. Selain motif ukir, motif-motif lain yang dikembangkan oleh para pembatik Jepara semuanya menunjukkan ciri khas budaya Jepara. Dengan demikian, maka batik Jepara menyimpan ikon-ikon Jepara melalui motif yang melekat padanya. Oleh karena itu, batik Jepara dapat dijadikan sebagai identitas baru bagi Jepara.

\section{Catatan}

${ }^{1}$ Buku ini merupakan hasil penelitian kerjasama dengan Museum Jawa Tengah Ranggawarsita yang dilakukan oleh Maziyah, dkk. pada 2015 dengan judul "Ragam Hias Pada Masjid Mantingan Jepara Sebagai Koleksi Museum yang Berbasis Ekonomi dan Tradisi bagi Masyarakat Setempat".

${ }^{2}$ Biyung Pralodo artinya adalah ibu yang gesit.
${ }^{3}$ Holing adalah sebutan Cina untuk Jepara pada abad ke-7 hingga abad ke-9.

4"Wilayah bawah angin" atau Nan-Yang atau Daerah Selatan adalah istilah yang digunakan oleh Cina dan Jepang untuk menyebut wilayah Asia Tenggara sebagai daerah pinggiran peradaban besar seperti India, Cina, dan Jepang (Reid, 2011a: xiv). Penunjukan arah mata angin itu berkaitan dengan kebiasaan para pedagang maritim ketika mengendalikan kapal sesuai dengan arah mata angin ke tempat yang dituju (Grimes, 1941).

${ }^{5}$ Buketan merupakan motif dengan mengambil bunga dan tumbuh-tumbuhan sebagai ornamen yang disusun memanjang selebar kain. Kata buketan berasal dari bahasa Perancis bouquetyang berarti rangkaian bunga.

${ }^{6}$ Motif galaran diilhami oleh adanya galaran, yaitu alas tempat tidur pada amben atau kursi panjang yang terbuat dari bambu yang dibelah kemudian ditata sedemikian rupa sehingga nyaman untuk digunakan sebagai alas. Galaran ini berbentuk lajuran, sehingga motif galaran juga memunculkan garis-garis simetris yang rapi. Motif ini melambangkan adanya kenyamanan di dalam kesederhanaan.

${ }^{7}$ Parang atau pereng menunjukkan adanya representasi yang bersifat miring.

${ }^{8}$ Gondosuli (Hedychium coronarium) adalah tanaman yang memiliki bunga majemuk putih yang harum.

${ }^{9}$ Kanthil (Magnolia $x$ alba) adalah pohon yang memiliki bunga putih kecil. Pohon ini tumbuh di dekat Pendopo Kabupaten Jepara yang menginspirasi R.A. Kartini untuk membuat motif batik.

${ }^{10}$ Lung atau elung adalah bentuk tananam menjalar yang melingkar.

${ }^{11}$ Untuk mengetahui pesta lomban dan perang obor, silakan baca penelitian Indrahti, dkk., (2016).

${ }^{12}$ Miyang adalah istilah lokal Jepara yang artinya mencari ikan.

${ }^{13}$ Lelangan adalah kegiatan yang dilakukan oleh nelayan setelah mereka kembali dari melaut untuk menjual hasil tangkapannya di Tempat Pelelangan Ikan.

${ }^{14}$ Trus Karya Tataning Bumi adalah candrasangkala atau penanda tahun penobatan Ratu Kalinyamat sebagai penguasa Jepara. Adapun 
arti dari kalimat itu adalah anjuran untuk bekerja keras untuk membangun Jepara.

${ }^{15}$ Kepis adalah salah satu alat tradisional sebagai tempat untuk menyimpan ikan hasil memancing.

${ }^{16}$ The Beauty of Java Tentik merupakan motif batik yang berasal dari gabungan motif tenun dan motif ukir di Jepara.

\section{Referensi}

Adrisijanti, I., \& Abdullah, T. (2015). Sejarah Kebudayaan Islam Indonesia: Khasanah Budaya Bendawi. Jilid 5. Jakarta: Direktorat Sejarah dan Nilai Budaya, Direktorat Jenderal Kebudayaan, Kementerian Pendidikan dan Kebudayaan.

Alamsyah, A. (2012). "Dinamika Sosial Ekonomi di Keresidenan Jepara 1830-1900.” Disertasi pada Universitas Padjadjaran.

Alamsyah, A. (2013). "Kreativitas Ekonomi Masyarakat Lokal di Karesidenan Jepara 18301900.” Paramita, Vol. 23 (1): 40-54. https://doi.org/10.15294/paramita.v23i1.24 95

Alamsyah, A. (2014). "Dinamika Perkembangan Industri Kerajinan Tenun Troso di Jepara." Humanika, Vol. 20 (2): 24-36. https://doi.org/10.14710/humanika.20.2.24 $-36$

Alamsyah, A. (2015). "Aktivitas Perdagangan di Keresidenan Jepara 1843-1891.” Paramita, Vol. 25 (1): 40-50. https://doi.org/10.15294/ paramita.v25i1.3420

Alamsyah, A. (2018). "Kerajinan Batik dan Pewarnaan Alami." Endogami: Jurnal Ilmiah Kajian Antropologi, Vol. 1 (2): 136-148. https://doi.org/10.14710/endogami.1.2. 136-148

Alamsyah, A., Supriyono, A., dan Maziyah, S. (2019). "Model Pengembangan Batik sebagai Komoditas Unggulan Melalui Penguatan Bahan Baku Pewarnaan Alami dan Motif Lokal di Jepara." Semarang: LPPM UNDIP.

Basuki, S. (2006). Metode Penelitian. Jakarta: Wedatama Widya Sastra-FIB UI.

Doellah, Santosa. (2002). Batik: Pengaruh Zaman dan Lingkungan. Surakarta: Danar Hadi.

Fatkhudin, A. (2010). "Kardinah Reksonegoro: Peranan dan Pemikirannya dalam
Pengembangan Masyarakat Tegal Tahun 1908-1945." Skripsi Universitas Diponegoro.

de Graaf, H. J., Pigeaud, Th. G. Th. (2003). Kerajaan Islam Pertama di Jawa: Tinjauan Sejarah Politik Abad XV dan XVI. Jakarta: Pustaka Utama Grafiti.

Grimes, A. (1941). “The Journey of Fa-Hsien from Ceylon to Canton.” pada Journal of Malaysian Branch Royal Asiatic Society, Vol. XIX (I): 7692. Tulisan ini diterbitkan kembali pada tahun 2007 oleh The Malaysian Branch of the Royal Asiatic Society dengan judul buku Southeast Asia-China Interactions: reprint of articles from the Journal of The Malaysian Branch, Royal Asiatic Society, hlm 167-182.

Groeneveldt, W. P. (2009). Nusantara dalam Catatan Tionghoa. Penterjemah: Gatot Triwira. Cetakan I.Jakarta: Komunitas Bambu. Gungwu, W. (2007). "The Nanhai Trade: A Study of the Early History of Chinese Trade in the South China Sea". Journal of Malaysian Branch Royal Asiatic Society, Vol. XXXI (2): 1-135.

Hayati, Chusnul, Supriyono, A., Sugiyarto, Maziyah, S., Purnomo, M. H. (2007). Ratu Kalinyamat: Biografi Tokoh Wanita Abad XVI dari Jepara, Cetakan I, Semarang: Pemerintah Kabupaten Jepara dan Pusat Penelitian Sosial Budaya Lembaga Penelitian Undip bekerja sama dengan Penerbit Jeda.

Indrahti, S., \& Laksono, A. (2014). "Pemetaan Klaster Kerajinan sebagai Model Pengembangan Wisata Kerajinan di Jepara," Laporan Penelitian Hibah Bersaing PNPB Tahun I. Semarang: LPPM UNDIP.

Indrahti, S. \& Laksono, A. (2015). "Pemetaan Klaster Kerajinan sebagai Model Pengembangan Wisata Kerajinan di Jepara," Laporan Penelitian Hibah Bersaing PNPB Tahun II, Semarang: Lembaga Penelitian dan Pengabdian Kepada Masyarakat UNDIP.

Indrahti, dkk. (2016). "Pemberdayaan Kuliner Berbasis Budaya bagi Pengembangan Wisata Terpadu di Kabupaten Jepara”, Laporan Penelitian Riset Pengembangan dan Penerapan Tahun I. Semarang: Lembaga Penelitian dan Pengabdian Kepada Masyarakat UNDIP. 
Kadir, A. (1979). Risalah dan Kumpulan Data tentang Perkembangan Seni Ukir Jepara. Jepara: Pemerintah Daerah Kabupaten Jepara.

Koentjaraningrat. (1997). Metode Penelitian Masyarakat. Jakarta: Gramedia.

Kohar, A. (2013). Sejarah Budaya Legenda ObyekObyek Wisata Jepara. Jepara: Dinas Pariwisata Jepara.

Leeuwendal, Th. C. (1931). "Hindoe-Javaanschen Stijl”, Oudheidkundig Verslag 1930. Uitgegeven door het: Koninklijk Bataviaasch Genootschap van Kunsten en Wetenschappen, Batavia-Centrum: Albrecht \& Co.

Maziyah, S. (2015). "Historis dan Filosofi Motif Batik Tegal”, Disampaikan dalam Workshop Motif Batik Tegalan Tahun 2015 Diselenggarakan oleh Dinas Koperasi UKM dan Pasar Kabupaten Tegal, 19 Oktober 2015.

Maziyah, S., Indrahti, S., dan Alamsyah, A. (2015a). "Ragam Hias pada Masjid Mantingan Jepara sebagai Koleksi Museum yang Berbasis Ekonomi dan Tradisi bagi Masyarakat Setempat”, Laporan Penelitian. Semarang: Museum Ranggawarsita Jawa Tengah.

Maziyah, S. (2015b). Ornamen Mantingan. Semarang: Museum Ranggawarsita Jawa Tengah.

Frederici, C. (1581). "The Voyage and Travell of M. Caesar Frederikce, Marchant of Venice, into the East India, and Beyond the Indies", trans. T. Hickocke, 1907. R. Hakluyt (Ed.) The Principal Navigations, Voyage, Traffiques, and Discoveries of the English Nation, Vol. III, Everyman's Edition. London: J. M. Dent.

Maziyah, S. (2017a). "Fungsi Kain Impor di Jawa pada Abad ke-9 hingga Abad ke-15 Berdasar Sumber Arkeologis." Student Weekly Forum 2017. Yogyakarta: Fakultas Ilmu Budaya UGM.

Maziyah, S. (2017b). "Imports Fabric at Java in $12^{\text {th }}-14^{\text {th }}$ Centuries: Impacts of Maritime Trade Route in Southeast Asia". Advanced Science Letters. Vol. 23. United States of America: American Scientific Publishers. Hlm. 10057-10060.

Maziyah, S. (2018a). "Nama Menujukkan Asal: Studi Kasus Nama Jenis Kain Pada Prasasti dan Susastra Berbahasa Jawa Kuna”. Makalah disampaikan dalam Seminar Nasional "Penelitian Terkini Prasasti Indonesia" yang diselenggarakan oleh Departemen Arkeologi UGM di Yogyakarta tanggal 6 Maret 2018.

Maziyah, S. (2018b). "Motif Batik Tegal: Pengaruh Mataram, Pesisiran dan Islam.” Endogami: Jurnal Ilmiah Kajian Antropologi, Vol. 1 (2): 180-193.

https://ejournal.undip.ac.id/index.php/endo gami/issue/view/2365

Nagtegaal, L. (1996). "Riding the Dutch Tiger: The Dutch East Indies Company and the Northeast Coast of Java, 1680-1743.” VKI, No. 171, Leiden: KITLV Press.

Qingxin, L. (2006). Maritime Silk Road. China: China Intercontinental Press.

Reid, A. (2011a). Asia Tenggara Dalam Kurun Niaga 1450-1680. Jilid 1: Tanah di Bawah Angin. Jakarta: Yayasan Pustaka Obor Indonesia.

Reid, A. (2011b). Asia Tenggara dalam Kurun Niaga 1450-1680. Jilid 2: Jaringan Perdagangan Global, diterjemahkan oleh R.Z. Leirissa dan P. Soemitro. Cetakan II. Jakarta: Yayasan Pustaka Obor Indonesia.

Rouffaer, R. H., Juynboll, H. (1914). De BatikKuns in Nederlandsch Indië en Haar Geschiedenis. Utrecht: Uitgave van A. Costhoek.

Susanto, S. (1973). Seni Kerajinan Batik Indonesia. Yogyakarta: Balai Penelitian Batik dan Kerajinan, Lembaga Penelitian dan Pendidikan Industri, Departemen Perindustrian Republik Indonesia.

Syamsudin, H. (2007). Metodologi Sejarah. Yogyakarta: Penerbit Ombak.

Toer, P. A. (2000). PanggilAku Kartini Saja. Cetak ulang ke-2. Jakarta: Hasta Mitra.

Triaji, Bintang. (2018). "Paguyuban Batik Biyung Pralodo: Kelahiran Kembali, Perkembangan, dan Strategi Perluasan Batik Jepara Tahun 2004-2015." Skripsi Program Studi S1 Sejarah, Universitas Diponegoro.

Zoetmulder. (2000). Kamus Jawa Kuna-Indonesia. Penerjemah bahasa Indonesia dari bahasa Inggris: Darusuprapta dan Sumarti Suprayitna. Cetakan ke-3. Jakarta: Gramedia Pustaka Utama. 
Wurjantoro, E. (2012). Prasasti Berbahasa Jawa Kuno Abad VII-X Masehi Koleksi Museum Nasional Jakarta (alih aksara dan terjemahan). Depok: t.p.

"Batik Kartini”. http://id.wikipedia.org/wiki/ Batik_Kartini dikunjungi pada 10 September 2014.

"Kisah Keluarga R.A. Kartini Angkat Derajad Bangsa Melalui Batik”. http://regional. liputan6.com/read/3116234/kisah-keluargara-kartini-angkat-derajat-bangsa-melalui-batik , diakses 30 November 2017.

"Silsilah Batik Kartini". https://gaya.tempo. co/silsilah-batik-kartini, diakses pada 10 September 2014.

http://wartawarga.gunadarma.ac.id/2009/12/tet apkan-batik-sebagai-warisan-budaya-indonesia/, diakses pada 7 Mei 2012.

\section{Daftar Informan}

Alfiah, Pemilik Gendhis Batik Jepara, Jepara. April Puji Astuti, Pemilik Stilir Batik, Jepara. Dewi Irawati, Pemilik Batik Sekar, Jepara.

Erlisa Sulasmi, Pemilik Batik Nabila, Jepara.

M. Latif Jauhari, Sekretaris Asosiasi Tenun Troso dan Konveksi (ASTTIKA) Jepara.

Nurunnikmah Awwalina, Pemilik Batik Kembang Mulyo, Jepara.

Sukim, Pemilik Mulyo Lestari, Jepara.

Suyanti Djatmiko, Pemilik Nalendra Galeri Batik Jepara.

Titik Susanti, Pemilik Ndugoasih (Batik Bandengan, Jepara. 